Check for updates

Cite this: RSC Adv., 2017, 7, 48019

Received 19th September 2017 Accepted 2nd October 2017

DOI: 10.1039/c7ra10389a

rsc.li/rsc-advances

\title{
Trichodermamides $D-F$, heterocyclic dipeptides with a highly functionalized 1,2-oxazadecaline core isolated from the endophytic fungus Penicillium janthinellum HDN13-309†
}

\author{
Meilin Zhu, ${ }^{\text {a }}$ Zhen Yang, ${ }^{\text {cd }}$ Huimin Feng, ${ }^{a}$ Qi Gan, ${ }^{a}$ Qian Che, ${ }^{a}$ Tianjiao Zhu, ${ }^{a}$ \\ Qianqun Gu, ${ }^{a}$ Bingnan $\mathrm{Han}^{* \mathrm{c}}$ and Dehai Li (D) *ab
}

\begin{abstract}
Three new heterocyclic dipeptides with a highly functionalized 1,2-oxazadecaline core, named trichodermamides $D-F(1-3)$, together with the known trichodermamides $A-C(4-6)$, were isolated from the broth of the mangrove-derived endophytic fungus Penicillium janthinellum HDN13-309. The structures were elucidated through extensive NMR spectroscopic and physical data. The absolute configurations of compounds 1-3 were determined by ECD calculations and single-crystal X-ray diffraction experiments. The cytoprotective activities were evaluated on different phase II detoxifying enzymes (SOD2, AKR1C1, HO-1 and NQO1), and compounds 4 and 6 showed potent inducing effects at the concentration of $10 \mu \mathrm{M}$.
\end{abstract}

\section{Introduction}

The trichodermamides are a family of heterocyclic dipeptides featuring the 1,2-oxazadecaline moiety which is connected to a $4 H$-chroman-4-one unit via an amide group. As rarely discovered fungal secondary metabolites, only a few analogues, namely, trichodermamides $\mathrm{A}-\mathrm{C}$, aspergillazines $\mathrm{A}-\mathrm{E}$ and dithioaspergillazine A have been reported from Trichoderma sp., ${ }^{1,2}$ Eupenicillium sp. ${ }^{3}$ and Aspergillus sp. ${ }^{4}$ The structural diversity of reported trichodermamides is mainly represented by the variety of substitutions on the cyclohexane ring of the 1,2oxazadecaline moiety (rings A and B). Although only very limited bioassays have been evaluated, trichodermamide B and dithioaspergillazine A have been reported to show cytotoxicity against the HCT-116 cell line with $\mathrm{IC}_{50}$ values of 0.7 and $1.3 \mu \mathrm{M}$,

${ }^{a}$ Key Laboratory of Marine Drugs, Chinese Ministry of Education, School of Medicine and Pharmacy, Ocean University of China, Qingdao 266003, People's Republic of China.E-mail: dehaili@ouc.edu.cn; Fax:+86-532-82033054; Tel: +86-532-82031632 ${ }^{b}$ Laboratory for Marine Drugs, Bioproducts of Qingdao National Laboratory for Marine Science and Technology, Qingdao, 266237, People's Republic of China

${ }^{c}$ Department of Development Technology of Marine Resources, College of Life Sciences, Zhejiang Sci-Tech University, Hangzhou 310018, People's Republic of China. E-mail: hanbingnan@zstu.edu.cn

${ }^{d}$ Research Center for Marine Drugs, Department of Pharmacy, State Key Laboratory of Oncogenes and Related Genes, Renji Hospital, School of Medicine, Shanghai Jiao Tong University, Shanghai 200127, China

$\dagger$ Electronic supplementary information (ESI) available: Detailed information of ECD calculations of compound 1, HPLC-UV analysis of the extract, the UPLC-MS analysis of compounds 1-6, HRESIMS, 1D and 2D NMR spectra of compounds 1-3. CCDC 1569990. For ESI and crystallographic data in CIF or other electronic format see DOI: 10.1039/c7ra10389a respectively. ${ }^{\mathbf{1 , 2}}$ Further studies by Jans et al. suggested that trichodermamide B could cause DNA double-strand breaks leading to accumulation of cells in the $S$ phase of the cell cycle

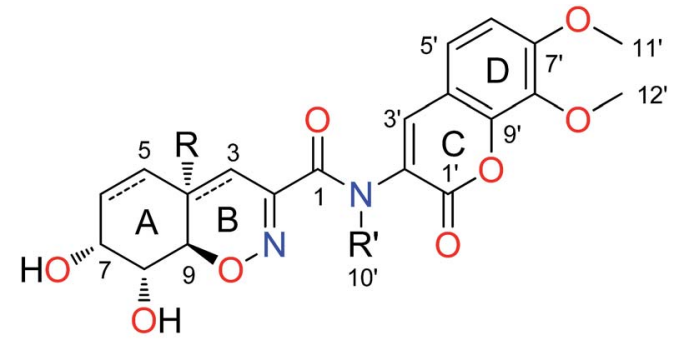

$$
\begin{aligned}
& 1 \mathrm{R}=O H, \mathrm{R}^{\prime}=\mathrm{H}, \Delta^{5,6} \\
& 2 \mathrm{R}=\mathrm{OH}, \mathrm{R}^{\prime}=\mathrm{H} \\
& 3 \mathrm{R}^{\prime}=\mathrm{Me}, \Delta^{3,4}, \Delta^{5,6}
\end{aligned}
$$<smiles>[R]C1C=C[C@@H](O)[C@H]2ON=C(C(=O)N([R])c3cc4ccc(OC)c(OC)c4oc3=O)C[C@]12O</smiles>

$$
\begin{aligned}
& 4 \mathrm{R}=\mathrm{OH}, \mathrm{R}^{\prime}=\mathrm{H} \\
& 5 \mathrm{R}=\mathrm{Cl}, \mathrm{R}^{\prime}=\mathrm{H} \\
& 6 \mathrm{R}=\mathrm{OH}, \mathrm{R}^{\prime}=\mathrm{Me}
\end{aligned}
$$

Fig. 1 The chemical structures of compounds 1-6. 
and subsequent initiation of apoptosis in HeLa cells. ${ }^{5}$ Driven by the structural novelty and potent bioactivity, total synthesis of trichodermamides A-C have been achieved. ${ }^{6-8}$

In our previous research, a serious of cytotoxic gliovirins (penicisulfuranols $\mathrm{A}-\mathrm{F}$ ) have been isolated from an active endophytic fungus Penicillium janthinellum HDN13-309.9,10 To obtain enough amounts of these compounds for further bioactive study, $P$. janthinellum HDN13-309 was re-cultured in a larger scale under the same condition and a series of compounds with UV absorptions different from gliovirins were observed as minor components (Fig. S1 in ESI $\dagger$ ). Continuous exploration led to the isolation of three new dipeptides named trichodermamides D-F (1-3) together with the known trichodermamides A-C (4-6) (Fig. 1). Among them, compounds 1-3 are the first trichodermamides with the double bond at $\mathrm{C}-5 / \mathrm{C}-6$ or two double bonds at both C-3/C-4 and C-5/C-6. Herein, we report the isolation, structure elucidation and bioactivity evaluation of compounds 1-6.

\section{Results and discussion}

The fungus $P$. janthinellum HDN13-309 was re-cultured (100 L) under static conditions at $28{ }^{\circ} \mathrm{C} .{ }^{9}$ The EtOAc extract ( $47 \mathrm{~g}$ ) was fractionated by column chromatography and semi-preparative HPLC guided by the UV absorptions, which led to the isolation of compounds 1-6.

Compound 1 was obtained as pale yellow powder with molecular formula $\mathrm{C}_{20} \mathrm{H}_{20} \mathrm{~N}_{2} \mathrm{O}_{9}$, established by HRESIMS ion at $m / z 433.1245[\mathrm{M}+\mathrm{H}]^{+}$, indicating 12 degrees of unsaturation. The ${ }^{1} \mathrm{H}$ and ${ }^{13} \mathrm{C}$ NMR spectroscopic data showed the presence of two oxygenated methyls, one $\mathrm{sp}^{3}$ methylene, eight methines (with five $\mathrm{sp}^{2}$ and three $\mathrm{sp}^{3}$ ones) and nine nonprotonated carbons including eight $\mathrm{sp}^{2}$ and one $\mathrm{sp}^{3}$ ones. Similarity of the 1D NMR data with those of trichodermamide A (4) indicated that they share the same skeleton. ${ }^{1}$ Detailed analysis of the $2 \mathrm{D}$ NMR correlations (Fig. 2) indicated that the major differences between $\mathbf{1}$ and $\mathbf{4}$ were the positions of double bond and a hydroxyl group in ring A. The COSY correlations $(\mathrm{H}-5 / \mathrm{H}-6 / \mathrm{H}-7 /$ $\mathrm{H}-8 / \mathrm{H}-9)$ and the HMBC correlations from $\mathrm{H}-5$ to $\mathrm{C}-3 / \mathrm{C}-7 / \mathrm{C}-9$, from $\mathrm{H}-6$ to $\mathrm{C}-4$, from $\mathrm{H}-3$ to $\mathrm{C}-1 / \mathrm{C}-2 / \mathrm{C}-9$ and from $4-\mathrm{OH}$ to $\mathrm{C}-$ 4 confirmed the structure of ring $\mathrm{A}$ with the double bond at $\mathrm{C}$ 5 and C-6. In addition, the chemical shift of C-7 $\left(\delta_{\mathrm{C}} 67.0\right)$ also indicated that the hydroxyl group was located at C-7. Thus the planar structure of compound 1 was established and the $\Delta^{5,6}$ and 7-OH distinguished $\mathbf{1}$ from other known trichodermamides such as compounds 4-6 ( $\Delta^{6,7}$ and 5-OH).

The relative configuration of 1 was deduced as $4 S^{*}, 7 R^{*}, 8 R^{*}$, $9 S^{*}$ on the basis of the NOESY data and coupling constants. The NOESY cross-peaks of $\mathrm{H}-7 / \mathrm{H}-8$ and the small coupling constant between them $\left(J_{\mathrm{H}-7 / \mathrm{H}-8}=4.5 \mathrm{~Hz}\right)$ indicated that $\mathrm{H}-7$ and $\mathrm{H}-8$ were cofacial of the hexane ring (ring A). The NOESY correlation of $4-\mathrm{OH} / \mathrm{H}-9$ and $\mathrm{H}-3 \mathrm{a} / \mathrm{H}-8$ suggested that $4-\mathrm{OH}$ and $\mathrm{H}-9$ oriented to the other side of the hexane ring (Fig. 3), which was also agree with the anti-configuration of $\mathrm{H}-8$ and $\mathrm{H}-9$ supported by the large coupling constant $\left(J_{\mathrm{H}-8 / \mathrm{H}-9}=10.9 \mathrm{~Hz}\right.$ ) (Table 1). The absolute configuration of $\mathbf{1}$ was determined by comparison of the experimental and computed ECD curves. ${ }^{11-13}$

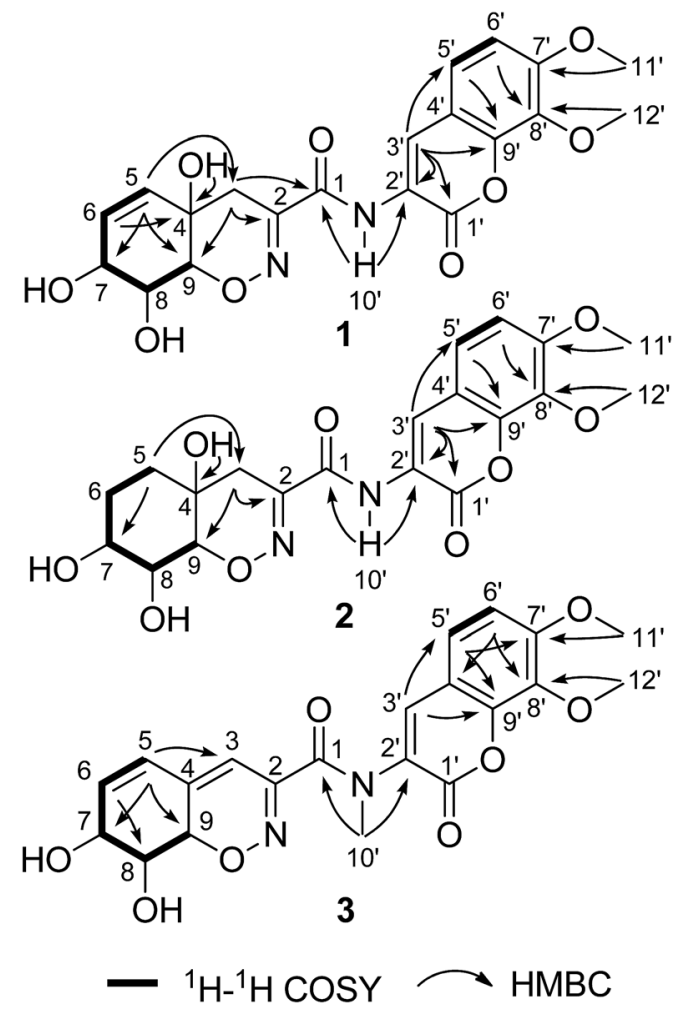

Fig. 2 Selected 2D NMR correlations for compounds 1-3.

The initial MMFF conformational search and subsequent DFT reoptimization at the $\mathrm{B} 3 \mathrm{LYP} / 6-31+\mathrm{G}$ (d) level of the arbitrarily chosen $(4 S, 7 R, 8 R, 9 S)-1$ provided four major lowest-energy conformers with $49.7 \%, 33.9 \%, 7.7 \%$ and $7.0 \%$ populations, respectively (Table S1 and Fig. S2 in ESI $\dagger$ ). The ECD spectrum of each conformer was calculated at the same basis set and the combination results showed well agreement with the experiment one (Fig. 4), which indicated the $4 S, 7 R, 8 R, 9 S$ absolute configuration of $\mathbf{1}$.

The chemical molecular of compound 2 was determined as $\mathrm{C}_{20} \mathrm{H}_{22} \mathrm{~N}_{2} \mathrm{O}_{9}$ based on the HRESIMS ion peak at $m / z 435.1385$ [M $+\mathrm{H}]^{+}$. The $1 \mathrm{D}$ NMR data of compound 2 were very close to those of $\mathbf{1}$. The major differences between 1 and 2 were the appearance of signals for two methylenes at $\delta_{\mathrm{H}} 1.58\left(\mathrm{H}_{2}-5\right.$ and $\left.\mathrm{H}_{2}-6\right)$ in 2 and the disappearance of signals for a double bond $\left(\Delta^{5,6}\right)$, indicating that the $\Delta^{5,6}$ double bond in 1 was saturated in 2 . The planar structure was also confirmed by COSY and HMBC correlations (Fig. 2). With the biosynthetic consideration and

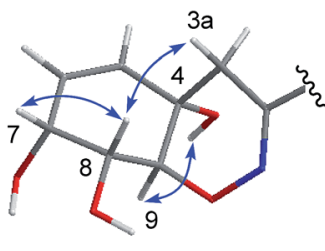

1

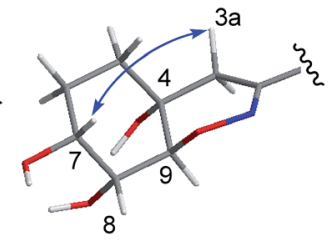

2
Fig. 3 Key NOESY correlations of compounds 1 and 2 . 
Table $1{ }^{1} \mathrm{H}(500 \mathrm{MHz})$ and ${ }^{13} \mathrm{C}(125 \mathrm{MHz})$ NMR data for compounds $1-3$ in DMSO- $d_{6}$

\begin{tabular}{|c|c|c|c|c|c|c|}
\hline \multirow[b]{2}{*}{ Position } & \multicolumn{2}{|l|}{1} & \multicolumn{2}{|l|}{2} & \multicolumn{2}{|l|}{3} \\
\hline & $\delta_{\mathrm{H}}(J$ in $\mathrm{Hz})$ & $\delta_{\mathrm{C}}$, type & $\delta_{\mathrm{H}}(J$ in $\mathrm{Hz})$ & $\delta_{\mathrm{C}}$, type & $\delta_{\mathrm{H}}(J$ in $\mathrm{Hz})$ & $\delta_{\mathrm{C}}$, type \\
\hline 2 & & 148.2, C & & 149.2, C & & 146.0, C \\
\hline 3 & a $2.58, \mathrm{~d}(18.9), \mathrm{b} 2.15, \mathrm{~d}(18.9)$ & 29.3, $\mathrm{CH}_{2}$ & a $2.24, \mathrm{~d}(19.0), \mathrm{b} 2.38, \mathrm{~d}(19.0)$ & 26.6, $\mathrm{CH}_{2}$ & 6.20, brs & 109.6, CH \\
\hline 4 & & $64.5, \mathrm{C}$ & & $66.9, \mathrm{C}$ & & 135.6, C \\
\hline 6 & 5.67, dd $(9.9,4.5)$ & $127.2, \mathrm{CH}$ & $1.58, \mathrm{~m}$ & 26.7, $\mathrm{CH}_{2}$ & 6.25, dd $(9.4,5.5)$ & $137.5, \mathrm{CH}$ \\
\hline 7 & 4.03, dd $(4.5,4.5)$ & $67.0, \mathrm{CH}$ & 3.59, brs & $71.6, \mathrm{CH}$ & $4.03, \mathrm{dd}(5.5,5.2)$ & $66.3, \mathrm{CH}$ \\
\hline 8 & 3.46, dd $(10.9,4.5)$ & $68.2, \mathrm{CH}$ & $3.44, \mathrm{~m}$ & $67.1, \mathrm{CH}$ & $3.56, \mathrm{~m}$ & $70.4, \mathrm{CH}$ \\
\hline 9 & $4.21, \mathrm{~d}(10.9)$ & $79.8, \mathrm{CH}$ & $3.91, \mathrm{~d}(10.6)$ & $83.7, \mathrm{CH}$ & $4.10, \mathrm{~d}(10.9)$ & $72.5, \mathrm{CH}$ \\
\hline $1^{\prime}$ & & $158.2, \mathrm{C}$ & & $158.3, \mathrm{C}$ & & $158.4, \mathrm{C}$ \\
\hline $2^{\prime}$ & & 121.3, C & & 121.3, C & & $128.2, \mathrm{C}$ \\
\hline $7^{\prime}$ & & 154.3, C & & 154.3, C & & $155.9, \mathrm{C}$ \\
\hline $8^{\prime}$ & & 135.7, C & & 135.7, C & & 135.7, C \\
\hline $9^{\prime}$ & & $144.0, \mathrm{C}$ & & 144.1, C & & 146.2, C \\
\hline $10^{\prime}$ & $9.31, \mathrm{~s}$ & & $9.31, \mathrm{~s}$ & & $3.23, \mathrm{~s}$ & $37.0, \mathrm{CH}_{3}$ \\
\hline $11^{\prime}$ & $3.88, \mathrm{~s}$ & $56.8, \mathrm{CH}_{3}$ & $3.88, \mathrm{~s}$ & $56.8, \mathrm{CH}_{3}$ & $3.90, \mathrm{~s}$ & $56.8, \mathrm{CH}_{3}$ \\
\hline $12^{\prime}$ & $3.82, \mathrm{~s}$ & $61.3, \mathrm{CH}_{3}$ & $3.82, \mathrm{~s}$ & $61.3, \mathrm{CH}_{3}$ & $3.82, \mathrm{~s}$ & $61.2, \mathrm{CH}_{3}$ \\
\hline
\end{tabular}

evidenced by the NOESY correlations of $\mathrm{H}-3_{\mathrm{a}} / \mathrm{H}-7$ (Fig. 3) as well as the large coupling constants between $\mathrm{H}-8$ and $\mathrm{H}-9(10.6 \mathrm{~Hz})$, the relative configuration of $\mathbf{2}$ was suggested the same to $\mathbf{1}$. Finally, the absolute configuration of $\mathbf{2}$ was determined as the same as 1 suggested by the similar ECD curves of them (Fig. 4).

Compound 3 was isolated as pale yellow needles and assigned the molecular formula $\mathrm{C}_{21} \mathrm{H}_{20} \mathrm{~N}_{2} \mathrm{O}_{8}$ on the basis of the HRESIMS ion peak at $m / z 429.1298[\mathrm{M}+\mathrm{H}]^{+}$. Comparing with 1 , the absence of signals for $\mathrm{H}_{2}-3$ of $\mathbf{1}$ and appearance of a $\mathrm{sp}^{2}$ methine $\left(\delta_{\mathrm{H}} 6.20, \mathrm{H}-3\right)$ signal of 3 indicated that the $4-\mathrm{OH}$ in 3 was substituted by a double bond. The replacement was further

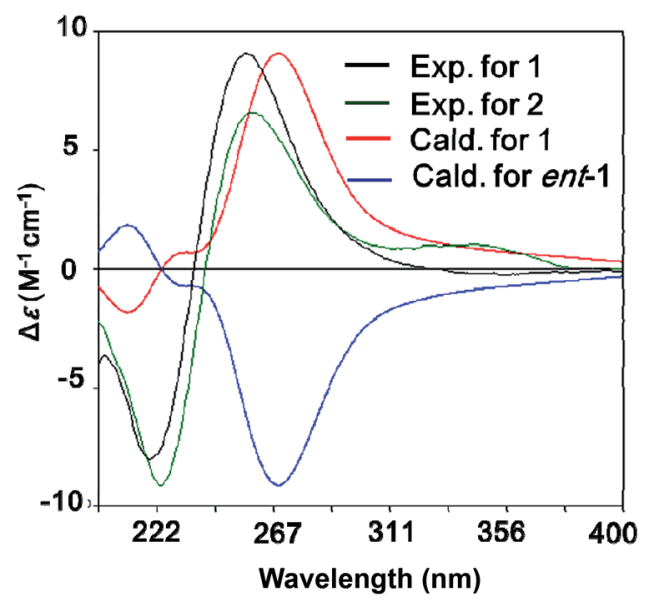

Fig. 4 B3LYP/6-31+G(d)-calculated ECD spectra of 1 (red) and its enantiomer (blue) and the experimental ones of 1 (black) and 2 (green) ( $\sigma=0.28 \mathrm{eV}$ for 1$)$. supported by the $\mathrm{HMBC}$ correlations from $\mathrm{H}-5$ to $\mathrm{C}-3\left(\delta_{\mathrm{C}} 109.6\right)$ (Fig. 2), and agreed with the degrees of unsaturation. Moreover, an extra methyl $\left(\delta_{\mathrm{H}} 3.23,10^{\prime}-\mathrm{CH}_{3}\right)$ signal and the HMBC correlations from $\mathrm{H}_{3}-10^{\prime}$ to $\mathrm{C}-1$ and $\mathrm{C}-2^{\prime}$ indicated the existence of a $N$-methyl. The coupling constants between $\mathrm{H}-7$ and $\mathrm{H}-8$ (5.2 $\mathrm{Hz})$ and between $\mathrm{H}-8$ and $\mathrm{H}-9(10.9 \mathrm{~Hz})$ also suggested the same relative configurations of C-7, C-8 and C-9 as $\mathbf{1}$ (Table 1 ). The absolute configuration of 3 was also deduced by the X-ray singlecrystal diffraction experiment $(\mathrm{Cu} \mathrm{K} \alpha$ radiation $(\lambda=1.54184 \AA)$; Flack parameter 0.05(11)) (Fig. 5).

The structures of known trichodermamides A-C (4-6) were identified by comparison of their spectroscopic and physical data $\left({ }^{1} \mathrm{H}\right.$ and ${ }^{13} \mathrm{C}$ NMR, MS, optical rotation) with those reported in the literature. ${ }^{1,3}$

Inspired by the previously reported chemical transformation from pretrichodermamide $\mathrm{A}$ to trichodermamide $\mathrm{A}$ under alkali

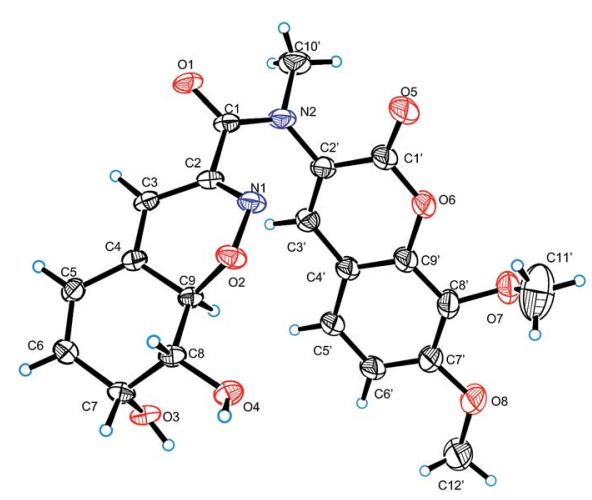

Fig. 5 X-ray crystallographic structure of compound 3. 
conditions,${ }^{14}$ we investigated whether the trichodermamides isolated from $P$. janthinellum HDN13-309 were artificial products. The fresh $\mathrm{CH}_{3} \mathrm{CN}$ extract of the fermentation product was analyzed by UPLC-UV-MS and compounds 1-6 were all detected (Fig. S3 in ESI $\dagger$ ). It was reported that pretrichodermamide A was stable under neutral and acidic conditions. ${ }^{14}$ The $\mathrm{pH}$ of the fermentation broth was also supervised and the values ranged from 6.0 to 5.0 during the culturing period. Based on the above data, compounds 1-6 were not considered as artificial products.

The cytotoxicity of compounds 1-6 were tested and only $\mathbf{5}$ was active. Including the reported cytotoxicity of 5 against HCT116 and HeLa, ${ }^{1,5}$ compound 5 also showed activities against K562, HL-60, HO-8910 and MGC803 (adriamycin as positive control) with $\mathrm{IC}_{50}$ values of 8.0, 1.8, 1.9 and $1.6 \mu \mathrm{M}$.

During the process of multiple cellular activities screening, compounds 1, 3, 4 and 6 were further tested cytoprotective activities by inducing the expression of phase II detoxifying enzymes, including superoxide dismutase 2 (SOD2), aldo-keto reductase family 1 member C1 (AKR1C1), heme oxygenase 1 (HO-1) and human $\mathrm{NAD}(\mathrm{P}) \mathrm{H}$ : quinone oxidoreductase 1 (NQO1). These antioxidant enzymes can prevent cells from various injuries of natural environment. In order to evaluate the antioxidant activities of these compounds in HaCaT cell, the cells were treated with these compounds $(10 \mu \mathrm{M})$ for $12 \mathrm{~h}$ and then the total protein was analyzed by western blotting experiment. Interestingly, compounds $\mathbf{4}$ and $\mathbf{6}$ significantly induced the level of AKR1C1, SOD2, while only slightly increased the protein expression of HO-1 and NQO1 in HaCaT cells (Fig. 6). Since cytoprotective proteins are induced as an adaptive response to mild oxidative and/or electrophilic stress as a safe guard against excessive ROS-induced cellular damage, compounds 4 and $\mathbf{6}$ might be able to function as antioxidants to protect cells from ROS damage.
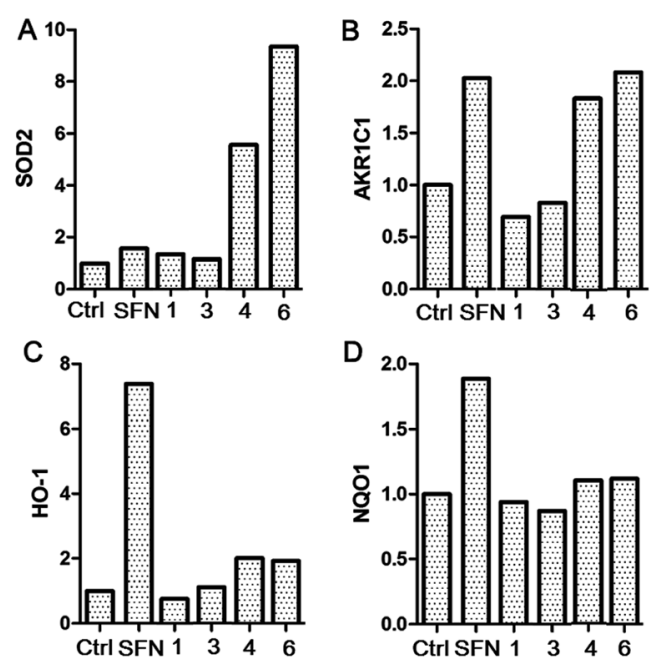

Fig. 6 Effect of compounds on SOD2 (A), AKR1C1 (B), HO-1 (C) and NQO1 (D) expression in HaCaT cells. Sulforaphane (SFN) was used as positive control. Cells were treated with compounds 1, 3, 4 and 6 (10 $\mu \mathrm{M})$ for $12 \mathrm{~h}$ to detect phase II detoxifying enzymes expression.

\section{Experimental section}

\section{General}

Optical rotations were measured with a JASCO P-1020 digital polarimeter. UV spectra were recorded on Beckman DU640 spectrophotometer. IR spectra were obtained with a Nicolet NEXUS 470 spectrophotometer in $\mathrm{KBr}$ discs. CD spectra were measured on JASCO J-715 or Chirascan CD spectropolarimeter. NMR spectra were recorded on a JEOL JNMECP 600 and Bruker400 spectrometers using TMS as an internal standard, with chemical shifts recorded as $\delta$ values. ESIMS was measured on a Micromass Q-TOF Ultima Global GAA076 LC mass spectrometer. HRESIMS was obtained with a Micromass EI-4000 (Autospec-Ultima-TOF). The human chronic myeloblastic leukemia K562 cells, human promyelocytic leukemia HL-60 cells, human cervical carcinoma HeLa cells, and human gastric mucous adenocarcinoma MGC803 cells were obtained from Shanghai Cell Bank, Chinese Academy of Science. Human ovarian cancer HO-8910 cells were provided by the American Type Culture Collection. The phase II detoxifying enzymes including SOD2, AKR1C1, HO-1 and NQO1 were obtained from Cell Signaling Technology.

\section{Strains and culture conditions}

The fungal strain HDN13-309 (GenBank accession number KM659023) was isolated from the root of mangrove plant Sonneratia caseolaris after disinfection, and was identified as Penicillium janthinellum by ITS sequence. A voucher specimen is deposited in our laboratory at $-20{ }^{\circ} \mathrm{C}$. The working strain was prepared on potato dextrose agar slants and stored at $4{ }^{\circ} \mathrm{C}$. The fungus $P$. janthinellum HDN13-309 was cultured for four weeks under static conditions at $28{ }^{\circ} \mathrm{C}$ in $1000 \mathrm{~mL}$ Erlenmeyer flasks containing $300 \mathrm{~mL}$ liquid medium containing maltose $(2 \%)$, mannitol $(2 \%)$, glucose $(1 \%)$, sodium glutamate $(1 \%)$, yeast extract $(0.3 \%)$, corn syrup $(0.1 \%), \mathrm{KH}_{2} \mathrm{PO}_{4}(0.05 \%)$ and $\mathrm{MgSO}_{4} \cdot 7 \mathrm{H}_{2} \mathrm{O}(0.03 \%)$ dissolved in naturally collected seawater (Huiquan Bay, Yellow Sea, Qiangdao, China).

\section{Purification}

The crude extract was applied to a silica gel (300-400 mesh) column and was separated into six fractions (fraction 1 to fraction 7) with a step gradient elution of $\mathrm{MeOH}-\mathrm{CH}_{2} \mathrm{Cl}_{2}$. Among these, fraction 4 was purified by Sephadex LH20 and further separated by semipreparative HPLC $\left(15: 85 \mathrm{CH}_{3} \mathrm{CN}-\right.$ $\mathrm{H}_{2} \mathrm{O}, 4 \mathrm{~mL} \mathrm{~min}^{-1}$ ) to obtain compound 4 (6.5 $\mathrm{mg}, t_{\mathrm{R}} 22 \mathrm{~min}$ ). Fraction 5 was applied on semi-preparative HPLC (20:80

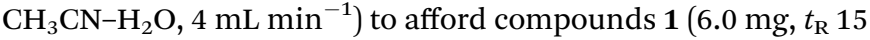
$\min$ ) and 2 (4.0 mg, $\left.t_{\mathrm{R}} 16 \mathrm{~min}\right)$. Fraction 6 was first purified by MPLC using stepwise gradient elution with 5-80\% $\mathrm{MeOH}-\mathrm{H}_{2} \mathrm{O}$ and then by semipreparative HPLC $\left(50: 50 \mathrm{MeOH}-\mathrm{H}_{2} \mathrm{O}, 4\right.$ $\left.\mathrm{mL} \min ^{-1}\right)$ to yield $3\left(5.5 \mathrm{mg}, t_{\mathrm{R}} 17 \mathrm{~min}\right)$. Fraction 7 was first purified by MPLC using stepwise gradient elution with $30-80 \%$ $\mathrm{MeOH}-\mathrm{H}_{2} \mathrm{O}$ and then by semipreparative HPLC (35:65 $\left.\mathrm{CH}_{3} \mathrm{CN}-\mathrm{H}_{2} \mathrm{O}, 4 \mathrm{~mL} \mathrm{~min}^{-1}\right)$ to afford compounds 5 (15.0 $\mathrm{mg}, t_{\mathrm{R}}$ $15 \mathrm{~min}$ ) and 6 (20.0 $\left.\mathrm{mg}, t_{\mathrm{R}} 20 \mathrm{~min}\right)$. 
Trichodermamide D (1). Pale yellow powder; $[\alpha]_{\mathrm{D}}^{25}+43.2(c$ 0.1, MeOH); IR (KBr) $\nu_{\max } 3396,2920,2850,1716,1608,1464$, 1288, 1013, 775, $696 \mathrm{~cm}^{-1}$; ECD $\left(0.74 \times 10^{-3} \mathrm{M}, \mathrm{MeOH}\right) \lambda_{\max }$ $(\Delta \varepsilon) 221$ (-8.33), 260 (9.50), $356(-0.56) \mathrm{nm} ;{ }^{1} \mathrm{H}$ and ${ }^{13} \mathrm{C}$ NMR see Table 1 ; HRESIMS $\mathrm{m} / \mathrm{z}$ 433.1245 $[\mathrm{M}+\mathrm{H}]^{+}$(calcd for $\mathrm{C}_{20} \mathrm{H}_{21} \mathrm{~N}_{2} \mathrm{O}_{9}, 433.1242$ ).

Trichodermamide E (2). Pale yellow powder; $[\alpha]_{\mathrm{D}}^{25}+40.2(c$ 0.1, MeOH); IR (KBr) $\nu_{\max } 3376,2944,2840,1700,1606,1460$, 1285, 1108, 983, 789, $694 \mathrm{~cm}^{-1} ; \operatorname{ECD}\left(0.57 \times 10^{-3} \mathrm{M}, \mathrm{MeOH}\right)$ $\lambda_{\text {max }}(\Delta \varepsilon) 222$ (-9.33), 260 (6.56), 356 (1.06) nm; ${ }^{1} \mathrm{H}$ and ${ }^{13} \mathrm{C} \mathrm{NMR}$ see Table 1 ; HRESIMS $m / z$ 435.1385 $[\mathrm{M}+\mathrm{H}]^{+}$(calcd for $\left.\mathrm{C}_{20} \mathrm{H}_{23} \mathrm{~N}_{2} \mathrm{O}_{9}, 435.1398\right)$.

Trichodermamide F (3). Pale yellow needles; $[\alpha]_{\mathrm{D}}^{25}-75.5(c$ 0.04, MeOH); UV (MeOH) $\lambda_{\max }(\log \varepsilon) 243(\mathrm{sh})$ (3.45), 313 (3.76) nm; IR (KBr) $\nu_{\max } 2355,1684,1601,1519,1460,1378$, 1284, 1102, $673 \mathrm{~cm}^{-1} ;{ }^{1} \mathrm{H}$ and ${ }^{13} \mathrm{C}$ NMR see Table 1; HRESIMS $m / z 429.1298[\mathrm{M}+\mathrm{H}]^{+}$(calcd for $\mathrm{C}_{21} \mathrm{H}_{21} \mathrm{~N}_{2} \mathrm{O}_{8}, 429.1292$ ).

\section{X-Ray crystallographic analysis}

An optically active colorlessly crystal of 3 was obtained in acetone $/ \mathrm{H}_{2} \mathrm{O}$. The crystal was kept at 295(2) $\mathrm{K}$ during data collection. A suitable crystal was selected and recorded with Xcalibur Eos Gemini single-crystal diffractometer with $\mathrm{Cu} \mathrm{K} \alpha$ radiation $(\lambda=1.54184 \AA)$. Using Olex $2,{ }^{15}$ the structure was solved with the ShelXS ${ }^{\mathbf{1 6}}$ structure solution program using Direct Methods and refined with the ShelXL ${ }^{17}$ refinement package using Least Squares minimisation. Crystallographic data have been deposited in the Cambridge Crystallographic Data Center with the deposition number CCDC 1569990. $\dagger$

Crystal data of trichodermamide $F$ (3). Monoclinic, space group $C 2$ (no. 5), $a=18.7697(4) \AA, b=4.89380(10) \AA, c=$ 22.9053(5) $\mathrm{A}, \beta=92.860(2)^{\circ}, V=2101.35(8) \AA^{3}, Z=4, T=295(2)$ $\mathrm{K}, \mu(\mathrm{CuK} \alpha)=0.890 \mathrm{~mm}^{-1}, D_{\text {calc }}=1.345 \mathrm{~g} \mathrm{~cm}^{-3}, 8010$ reflections measured $\left(7.73^{\circ} \leq 2 \Theta \leq 142.722^{\circ}\right), 3710$ unique $\left(R_{\text {int }}=\right.$ $\left.0.0224, R_{\text {sigma }}=0.0206\right)$ which were used in all calculations. The final $R_{1}$ was $0.0459(I>2 \sigma(I))$ and $\mathrm{w} R_{2}$ was 0.1292 (all data). Crystal size $0.270 \times 0.250 \times 0.210 \mathrm{~mm}^{3}$; Flack parameter $=$ $0.05(11)$.

\section{Computation section}

Conformational searches were run by employing the "systematic" procedure implemented in Spartan'14 (ref. 18) using MMFF (Merck molecular force field). All MMFF minima were reoptimized with DFT calculations at the B3LYP/6-31+G(d) level using the Gaussian09 program. ${ }^{19}$ The geometry was optimized starting from various initial conformations, with vibrational frequency calculations confirming the presence of minima. Time-dependent DFT calculations were performed on four lowest-energy conformations for $(4 S, 7 R, 8 R, 9 S)-1$ ( $>5 \%$ population) using 20 excited states, and using a polarizable continuum model (PCM) for MeOH. ECD spectra were generated using the program SpecDis ${ }^{20}$ by applying a Gaussian band shape with $0.28 \mathrm{eV}$ width for 1 , from dipole length rotational strengths. The dipole velocity forms yielded negligible differences. The spectra of the conformers were combined using Boltzmann weighting, with the lowest-energy conformations accounting for about $98 \%$ of the weights. The calculated spectra were shifted by $5 \mathrm{~nm}$ to facilitate comparison to the experimental data.

\section{Bioassays}

Cytotoxic activities of 1-6 were evaluated against six human tumor cell lines, including K562 (human chronic myeloblastic leukemia), HL-60 (human promyelocytic leukemia cells), HeLa (human cervical carcinoma cell line), HO-8910 (human ovarian cancer cell line) and MGC803 (human gastric cancer cell line), using the SRB and MTT methods. ${ }^{21,22}$ Adriamycin was used as the positive control.

The expression phase II metabolic enzymes were detected by western blot analysis. HaCaT cells were treated with compounds $(10 \mu \mathrm{M})$ for $12 \mathrm{~h}^{.3,24}$ Cells were harvested and lysed with cell lysis buffer, enriched with a complete protease inhibitor, PMSF, and then incubated on ice for $30 \mathrm{~min}$ with regular vortexing before centrifuging at $12000 \mathrm{rpm}$ at $4{ }^{\circ} \mathrm{C}$ for $15 \mathrm{~min}$. Protein concentration was determined by using BCA kit. The protein samples were boiled in $5 \times$ SDS sample buffer for $5 \mathrm{~min}$ and were resolved on a $10 \%$ SDS polyacrylamide gel. After electrophoresis, proteins were transferred onto polyvinyl difluoride (PVDF) membrane, which was blocked with 5\% nonfat dry milk in $1 \times$ TBST (Tris-buffered saline with $0.1 \%$ Tween-20) and incubated with primary antibody at the appropriate final concentration followed by hybridization with horseradish peroxidase-conjugated anti-rabbit or anti-mouse secondary antibodies $(1: 5000)$ followed by ECL detection. For each step, the membrane was washed with $1 \times$ TBST buffer three times for $10 \mathrm{~min}$ each.

\section{Conclusions}

In summary, six heterocyclic dipeptides (1-6) were isolated from the mangrove endophytic fungus $P$. janthinellum HDN13309. Trichodermamides D-F (1-3) are new ones possessing a rare 1,2-oxazadecaline moiety with the different replacement of the double bond from the known ones. The noncytotoxic compounds 4 and 6 exhibited significant cytoprotective activities which might be able to function as antioxidants.

\section{Conflicts of interest}

There are no conflicts to declare.

\section{Acknowledgements}

This work was financially supported by the National Natural Science Foundation of China (21372208, and 81373321), the Shandong Provincial Natural Science Fund for Distinguished Young Scholars (JQ201422), AoShan Talents Program Supported by Qingdao National Laboratory for Marine Science and Technology (2015ASTP-ES09), NSFC-Shandong Joint Fund for Marine Science Research Centers (U1606403), Shandong province key research and development program (2016GSF201204), Fundamental Research Funds for the Central Universities 
(201564026), the Scientific and Technological Innovation Project Financially Supported by Qingdao National Laboratory for Marine Science and Technology (2015ASKJ02).

\section{Notes and references}

1 E. Garo, C. M. Starks, P. R. Jensen, W. Fenical, E. Lobkovsky and J. Clardy, J. Nat. Prod., 2003, 66, 423-426.

2 H. Yamazaki, H. Rotinsulu, O. Takahashi, R. Kirikoshi and M. Namikoshi, Tetrahedron Lett., 2016, 57, 5764-5767.

3 R. A. Davis, J. Longden, V. M. Avery and P. C. Healy, Bioorg. Med. Chem. Lett., 2008, 18, 2836-2839.

4 R. J. Capon, R. Ratnayake, M. Stewart, E. Lacey, S. Tennant and J. H. Gill, Org. Biomol. Chem., 2005, 3, 123-129.

5 P. E. Jans, A. M. Mfuh, H. D. Arman, C. V. Shaffer, O. V. Larionov and S. L. Mooberry, J. Nat. Prod., 2017, 80, 676-683.

6 C. D. Lu and A. Zakarian, Angew. Chem., Int. Ed., 2008, 47, 6829-6831.

7 X. Wan and M. M. Joullié, J. Am. Chem. Soc., 2008, 130, 17236-17237.

8 A. M. Mfuh, Y. Zhang, D. E. Stephens, A. X. T. Vo, H. D. Arman and O. V. Larionov, J. Am. Chem. Soc., 2015, 137, 8050-8053.

9 M. Zhu, X. Zhang, H. Feng, J. Dai, J. Li, Q. Che, Q. Gu, T. Zhu and D. Li, J. Nat. Prod., 2017, 80, 71-75.

10 D. Li, M. Zhu, Q. Gu, T. Zhu, J. Li and Q. Che, Faming Zhuanli Shenqing, ZL 105037397B, 2015.

11 J. Peng, H. Gao, J. Li, J. Ai, M. Geng, G. Zhang, T. Zhu, Q. Gu and D. Li, J. Org. Chem., 2014, 79, 7895-7904.

12 H. Gao, W. Liu, T. Zhu, X. Mo, A. Mándi, T. Kurtán, J. Li, J. Ai, Q. Gu and D. Li, Org. Biomol. Chem., 2012, 10, 9501-9506.

13 W. Guo, D. Li, J. Peng, T. Zhu, Q. Gu and D. Li, J. Nat. Prod., 2015, 78, 306-310.

14 P. Seephonkai, P. Kongsaeree, S. Prabpai, M. Isaka and Y. Thebtaranonth, Org. Lett., 2006, 8, 3073-3075.
15 O. V. Dolomanov, L. J. Bourhis, R. J. Gildea, J. A. K. Howard and H. Puschmann, J. Appl. Crystallogr., 2009, 42, 339-341.

16 G. M. Sheldrick, Acta Crystallogr., 2015, A71, 3-8.

17 G. M. Sheldrick, Acta Crystallogr., 2015, C71, 3-8.

18 Spartan'14, Wavefunction Inc., Irvine, CA, 2013.

19 M. J. Frisch, G. W. Trucks, H. B. Schlegel, G. E. Scuseria, M. A. Robb, J. R. Cheeseman, G. Scalmani, V. Barone, B. Mennucci, G. A. Petersson, H. Nakatsuji, M. Caricato, X. Li, H. P. Hratchian, A. F. Izmaylov, J. Bloino, G. Zheng, J. L. Sonnenberg, M. Hada, M. Ehara, K. Toyota, R. Fukuda, J. Hasegawa, M. Ishida, T. Nakajima, Y. Honda, O. Kitao, H. Nakai, T. Vreven, J. A. Montgomery Jr, J. E. Peralta, F. Ogliaro, M. Bearpark, J. J. Heyd, E. Brothers, K. N. Kudin, V. N. Staroverov, R. Kobayashi, J. Normand, K. Raghavachari, A. Rendell, J. C. Burant, S. S. Iyengar, J. Tomasi, M. Cossi, N. Rega, J. M. Millam, M. Klene, J. E. Knox, J. B. Cross, V. Bakken, C. Adamo, J. Jaramillo, R. Gomperts, R. E. Stratmann, O. Yazyev, A. J. Austin, R. Cammi, C. Pomelli, J. W. Ochterski, R. L. Martin, K. Morokuma, V. G. Zakrzewski, G. A. Voth, P. Salvador, J. J. Dannenberg, S. Dapprich, A. D. Daniels, Ö. Farkas, J. B. Foresman, J. V. Ortiz, J. Cioslowski and D. J. Fox, Gaussian 09, Revision A.1, Gaussian, Inc., Wallingford, CT, 2009.

20 T. Bruhn, Y. Hemberger, A. Schaumlöffel and G. Bringmann, SpecDis, Version 1.53, University of Wuerzburg, Germany, 2011.

21 L. Du, T. Feng, B. Y. Zhao, D. H. Li, S. X. Cai, T. J. Zhu, F. P. Wang, X. Xiao and Q. Q. Gu, J. Antibiot., 2010, 63, 165-170.

22 T. Mosmann, J. Immunol. Methods, 1983, 65, 55-63.

23 B. W. Bolling and K. L. Parkin, Food Chem., 2009, 113, 10691075.

24 J. S. Park, J. S. Jung, Y. H. Jeong, J. W. Hyun, T. K. V. Le, D. H. Kim, E. C. Choi and H. S. J. Kim, Neurochemistry, 2011, 119, 909-919. 